\title{
Observations on the use of visual and olfactory cues by Trigona spp foragers
}

\author{
JD Villa ${ }^{1, *}$, MR Weiss ${ }^{2}$ \\ 1 USDA, ARS Honey-Bee Breeding, Genetics and Physiology Laboratory, \\ 1157 Ben Hur Rd, Baton Rouge, LA 70820-5502; \\ 2 University of California, Department of Integrative Biology, Berkeley, CA 94720, USA
}

(Received 24 April 1990; accepted 25 July 1990)

\begin{abstract}
Summary - Foragers of Trigona species were trained to artificial feeders associated with either yellow or blue colors, and the bees learned to associate the visual cues with a food reward. While feeding, foragers marked the plastic dishes with odors, which were later recognized by their nestmates. Odors left by foragers from different colonies of a single species elicited a positive response, while odors left by foragers of a different species elicited no noticeable response.
\end{abstract}

Trigona / learning / conditioning / visual cue / olfactory cue

\section{INTRODUCTION}

The simultaneous use of color and odor cues at feeders by Apis mellifera foragers has been widely studied (von Frisch, 1967). Although one might expect the social Meliponini to have similar capabilities, information on their use of odor and color cues in foraging is scant. The use of odor trails in nestmate recruitment has been demonstrated for many species of Trigona, but has not been found in Melipona (von Frisch, 1967). Conditioning to color at artificial feeders was demonstrated in Melipona (Pessotti, 1981; Pessotti and Carli Gomes, 1981), and conditioning to colors at the entrance of a Trigona nest was shown by Lutz (1933). We evaluated the use of color and odor cues by foragers at feeders for several species of Trigona.

\section{MATERIALS AND METHODS}

Two colonies of $T$ angustula (previously known as $T$ jaty) and 1 colony of $T$ mexicana at $\mathrm{La}$ Selva Biological Station in Sarapiqui, Heredia, Costa Rica, were trained to artificial feeders. Drops of unscented $40 \%$ sucrose solution at the tip of a 25- $\mu$ l capillary tube were presented at the entrance to the colony, and workers were allowed to feed for several min. Once at least 5 workers were trained to feed from the capillary tube, a plastic Petri dish containing a small amount of syrup was held at an angle touching the nest entrance such that workers could crawl over the feeder. After several workers had fed from the Petri dish, it was moved a short distance away from the entrance of the nest, so that workers had to fly to the dish in order to feed. The dish was slowly moved further away, in steps of approximately $25 \mathrm{~cm}$ every $5 \mathrm{~min}$, until it was placed on a table approximately $2 \mathrm{~m}$ distant from the nest entrance.

\footnotetext{
${ }^{*}$ Correspondence and reprints.
} 
Once bees were regularly visiting the feeder tables, squares of either yellow or blue construction paper were placed beneath the transparent sugar-containing dishes. The yellow and blue were similar in brightness, as measured by a camera light meter. Each colony was assigned 1 color, which was consistently offered with the sugar syrup. One $T$ angustula colony was trained to yellow, the other to blue. The $T$ mexicana colony was trained to blue. Prelimina$r y$ trials indicated that foragers left odors on the dishes while feeding, so some subsequent trials incorporated odor cues as well. Once foraging had taken place for at least $3 \mathrm{~h}$, discrimination tests which evaluated the bees' responses to various combinations of color and odor cues were carried out.

In all trials the bees were presented with a pair of dishes placed approximately $20 \mathrm{~cm}$ apart on the feeder tables. For the color trials, the paired dishes presented different combinations of trained and untrained colors. For the trials which incorporated odor cues, clean (unused) and odor-marked (from previous visits) dishes were used in various combinations with the colors. During all trials, the sugar solution was replaced by water. A dish containing sugar syrup was placed on the table for at least 10 min between each trial so as not to lose potential foragers.

To test whether bees responded to the odor marks of non-nestmate conspecifics, dishes marked by foragers from 1 colony of $T$ angustula were used in trials with the other colony. To evaluate the bees' response to odors from a different species, a dish heavily marked by $T$ peckolti (a third species whose foragers found 1 of our feeders) was used in a trial with experienced $T$ angustula foragers.

To evaluate the responses of untrained bees, all experienced $T$ mexicana foragers were netted at the feeder. To assess the bees' color preferences, arriving new recruits were presented with a choice of both colors, without odor. In order to test the importance of odor cues in the absence of trained color, the untrained $T$ mexicana foragers were given a choice between a clean dish and a dish marked with their own odor.

For all trials, the likelihood of obtaining the observed visitation rate was calculated for a theoretical distribution of equal probability for alternate events. A binomial distribution was used when total number of visits ranged from 4 to 25 , and a normal distribution when visits were $>25$.

\section{RESULTS}

\section{Color trials (table I)}

$T$ angustula foragers trained to yellow, when offered a choice of 2 odorless yellow dishes, visited them in equal numbers. Foragers trained to a given color preferentially visited the training colored dish when offered a choice of both colors with odorless dishes. Foragers from the $T$ angustula colony trained to yellow visited the yellow dishes significantly more than they did the blue dishes, and, conversely, foragers from the colony trained to blue significantly favored that color. Position of the test dishes on the table did not appear to affect the outcome of these trials.

Table I. Color trials: number of landings by trained Trigona angustula foragers during $5 \mathrm{~min}$ periods. The color to which the foragers were trained is indicated. The colors associated with the dishes are indicated as $T$ (training color) or $\mathrm{U}$ (untrained color). Left and Right indicate position on the feeder table.

\section{Training color Dish Probability Left Right}

\begin{tabular}{lrrr}
\hline Yellow & $26 \mathrm{~T}$ & $20 \mathrm{~T}$ & 0.230 \\
Yellow & $65 \mathrm{~T}$ & $10 \mathrm{U}$ & $<0.001$ \\
Yellow & $4 \mathrm{U}$ & $77 \mathrm{~T}$ & $<0.001$ \\
Blue & $15 \mathrm{~T}$ & $0 \mathrm{U}$ & $<0.001$ \\
Blue & $0 \mathrm{U}$ & $8 \mathrm{~T}$ & 0.046 \\
\hline
\end{tabular}




\section{Color and odor trials (table II)}

When trained $T$ angustula foragers were offered a choice between their training color in association with odor markings left by nestmate foragers, and the same color without any odor, they landed more frequently on the dish with the odor. When foragers were offered a choice between their training color without odor, and their nontrained color with odor markings, they landed more frequently on the dish with the odor, even though it was presented with the non-training color.

Table II. Color and odor trials: number of landings by trained Trigona angustula foragers during 5 min periods. Test dishes offered various combinations of color and odor. The options are indicated as: training color $(\mathrm{T})$, untrained color (U), markings by nestmates (Odor), clean dish (No odor).

\begin{tabular}{|c|c|c|c|}
\hline \multirow[t]{2}{*}{ Training color } & \multicolumn{2}{|c|}{ Dish } & \multirow[t]{2}{*}{ Probability } \\
\hline & Odor & No odor & \\
\hline Blue & $20 \mathrm{~T}$ & $2 T$ & $<0.001$ \\
\hline Yellow & $53 \mathrm{~T}$ & $11 \mathrm{~T}$ & $<0.001$ \\
\hline Yellow & $39 \mathrm{~T}$ & $2 U$ & $<0.001$ \\
\hline Yellow & $48 U$ & $6 \mathrm{~T}$ & $<0.001$ \\
\hline Yellow & $67 U$ & $3 \mathrm{~T}$ & $<0.001$ \\
\hline
\end{tabular}

\section{Nestmate and non-nestmate odor-trials (table III)}

When foragers from the $T$ angustula colony trained to yellow were offered a choice between 2 yellow dishes, 1 without odor and the other marked with odor from the other $T$ angustula colony, their responses were similar to those in which the odor came from their own colony. When the bees were offered a choice between a dish marked by nestmates and a dish marked by foragers of another species ( $T$ peckolti), all visits were to the dish with the nestmate odor.

Table III. Nestmate and non-nestmate odor trials: number of landings by trained Trigona angustula foragers during $5 \mathrm{~min}$ periods. Test dishes offered trained color with different odor choices.

\section{Odor choice}

Probability

$\begin{array}{ccc}\text { No odor } & \text { Nestmate odor } \\ 2 & 20 & <.001 \\ \text { No odor } & \text { Other T angustula colony } \\ 20 & 76 & <0.001 \\ \text { Nestmate odor } & \text { Other species (T peckolt) } \\ 4 & 0 & 0.062\end{array}$

\section{Untrained responses (table IV)}

An untrained cohort of $T$ mexicana visited odorless yellow and blue colored dishes in equal numbers, but went exclusively to the dish previously visited by conspecific foragers when presented with 2 blue dishes.

Table IV. Untrained responses: number of landings by a recruited but untrained cohort of Trigona mexicana foragers during 5 min periods. The combinations of cues on the dishes are indicated.

\section{Color and odor choice Probability}

\begin{tabular}{lccc} 
No odor: & Blue & Yellow & \\
Blue color: & 13 & 14 & 0.427 \\
& Odor & No odor & \\
& 13 & 0 & $<0.001$ \\
\hline
\end{tabular}




\section{CONCLUSIONS}

Our results demonstrate that both color and odor cues are important in Trigona foragers' decisions to visit feeders. The bees can clearly learn to associate color with a food reward, in the absence of odor cues, and conversely, can respond to odor cues in the absence of, or in contradiction to, color cues. In nature, floral odors may provide the foragers with another cue, operating at short or long distances.

That a group of untrained foragers did not discriminate between yellow and blue feeders suggests that these bees did not have a strong learned or innate preference for either color. That these same bees showed a clear preference for the odormarked feeder, in the absence of color cues, indicates that the foragers' marking of nectar sources provides a cue for later visitors.

The fact that the bees responded to odor markings left by conspecific, nonnestmate foragers, suggests that the volatile compounds or blend of compounds which comprise forager marks may be species-specific. Species-specific recognition of volatiles was shown by Weaver et al (1975), who found that 3 Trigona species varied in their defensive responses to different concentrations of the most common components of Trigona madibular glands.

While Trigona spp foragers are important floral visitors, both as legitimate pollinators and as nectar and pollen thieves, surprisingly little is known about the cues that the bees use in locating flowers. This study has shown that Trigona foragers make use of color cues as well as odor markings left by earlier foragers. Further research is needed to clarify a number of other questions, including the role played by floral odors, the possible existence of innate color preferences, and the speciesor colony-specificity of odor marks.

\section{ACKNOWLEDGMENTS}

Experiments were performed during Organization for Tropical Studies course 87-1 (Organization for Tropical Studies). Funds for JDV were provided by the Department of Entomology and the OTS fund (Louisiana State University) and for MRW by the Department of Botany and the Graduate Division (University of California, Berkeley). CD Michener kindly identified voucher specimens. The study was carried out in cooperation with the Louisiana Agricultural Experiment Station.

Résumé - Observations sur l'utilisation de signaux visuels et olfactifs par les butineuses de Trigona spp. Des butineuses de 3 espèces de Trigona ont été conditionnées à des sources artificielles de nourriture en association avec des cartes de couleur jaune ou bleue et les abeilles ont appris à associer les signaux visuels à une récompense constituée par de la nourriture. En outre, les butineuses ont effectué des marquages odorants sur les plats visités. Les tests de choix comportaient 2 paires de nourrisseurs; des combinaisons des signaux testés étaient associées à chaque nourrisseur.

Chez 2 colonies de $T$ angustula conditionnées l'une au bleu, l'autre au jaune, les butineuses ont préféré de façon significative la couleur de conditionnement parmi les 2 couleurs proposées. Lorsqu'on a offert aux 2 colonies des choix combinant les 2 couleurs avec des plats nouveaux et des plats marqués olfactivement (visités auparavant par des congénères), les signaux couleur et odeur ont semblé se renforcer lorsqu'ils étaient présentés ensemble. Quand la couleur et l'odeur étaient contradictoires, la présence de l'odeur détermi- 
nait les atterrissages, même si la couleur offerte n'était pas la couleur de conditionnement.

Les butineuses d'une colonie de $T$ angustula ont préféré les plats visités par les butineuses d'une autre colonie de la même espèce à des plats neufs et préféré les plats visités par des congénères de leur colonie à ceux visités par $T$ peckolti. Les ouvrières d'un groupe non conditionné de $T$ mexicana n'ont montré aucune préférence pour les plats jaunes par rapport aux bleus mais ne se sont posées que sur les plats déjà visités par des congénères du nid.

Trigona / apprentissage / conditionnement / stimulus visuel / stimulus olfactif

\section{Zusammenfassung - Beobachtungen} über die Benutzung von Seh- und Geruchsreizen durch Sammelbienen von Trigona spp. Sammelbienen von drei Trigonen-Arten wurden auf künstliche Futterstellen trainiert, die jeweils mit blauen oder gelben Karten markiert waren. Die Bienen lernten die Sehreize zusammen mit einer Futterbelohnung. Außerdem markierten die Sammelbienen die besuchten Gefäße offensichtlich mit Duftmarken. Es wurden Wahlversuche mit Paaren von Futterstellen durchgefürhrt, bei denen mit jedem Futtergefäß Kombinationen von Testreizen verbunden wurden.

Bei zwei Völkern von $T$ angustula, von denen das eine auf Blau und das andere auf Gelb dressiert war, bevorzugten die Sammlerinnen in Wahlversuchen zwischen den beiden Farben signifikant ihre eigene Dressurfarbe. Wurde den beiden Völkern von $T$ angustula Kombinationen von Dressur- und Nichtdressurfarben mit neuen und geruchsmarkierten Gefäßen (die vorher von Nestgefährten besucht worden waren) angeboten, so schienen sich Farbe und Geruch gegenseitig zu verstärken, falls sie gleichsinnig dargeboten wurden. Standen aber Farbe und Geruch zueinander im $\mathrm{Ge}$ gensatz, so bestimmte der Geruch die Landung, auch wenn die dargebotene Farbe nicht die Dressurfarbe war.

Sammlerinnen eines Volkes von $T$ angustula bevorzugten Gefäße, die vorher von Beinen eines anderen Volkes derselben Art besucht worden waren gegenüber unbenutzten Gefäßen; sie bevorzugten von ihren eigenen Nestgefährten besuchte Gefäße gegenüber Gefäßen, die von $T$ peckolti angeflogen worden waren. Eine undressierte Gruppe von $T$ mexicana zeigte keine Vorliebe für gelbe gegenüber blauen Futterstellen, sondern sie landeten ausschließlich an Gefäßen, die von ihren Nestgefährten besucht worden waren.

\section{Trigona / Lernen / Konditionierung / Sehreize / Geruchsreize}

\section{REFERENCES}

von Frisch $\mathrm{K}$ (1967) The Dance Language and Orientation of Bees. Harvard University, Cambridge, MA, $566 \mathrm{p}$

Lutz FE (1933) Experiments with "stingless bees" (Trigona cressoni parastigma) concerning their ability to distinguish ultraviolet patterns. Am Mus Novit 641, 1-26

Pessotti I (1981) Aprendizagem em abelhas. VI: Discriminaçao condicional em Melipona rufiventris. Rev Bras Biol 41, 681-693

Pessotti I, Carli Gomes MJ (1981) Aprendizagem em abelhas. III. Discriminaçao com tres tipos de estimulos visuais. Rev Bras Biol 41, 667-672

Weaver N, Weaver EC, Clarke ET (1975) Reactions of five species of stingless bees to some volatile chemicals and to other species of bees. $J$ Insect Physiol 21, 479-494 